\title{
E-Tourism Dalam Pengenalan Sektor Pariwisata Berbasis Android Di Kota Makassar
}

\author{
Syamsul Bhahri \\ Teknik Informatika \\ Sekolah Tinggi Manajemen Informatika dan Komputer (STMIK) \\ Kharisma Makassar \\ syamsulbahri@kharisma.ac.id,
}

\begin{abstract}
Abstrak
Penelitian ini bertujuan untuk merancang pemanfaatan E-tourism untuk pemasaran sektor pariwisata di kota Makassar berbasis android. Fungsi dari penelitian ini adalah agar memudahkan para vendor yang ingin mencari lokasi wisata dan tempat wisata yang ingin di beli atau di kembangkan dan Fungsi lain dari penelitian adalah memudahkan pengguna untuk memberi informasi kepada vendor baik instansi maupun perseorangan yang ingin megembangkan atau membeli tempat wisata yang di tuju Pengumpulan data dengan mempelajari bahan, konsep, buku-buku dan teori yang berkaitan dengan proses penyusunan dan pembahasan masalah yang di bahas oleh penulis termasuk di dalam literatur tentang penulis dan mengenai hal-hal yang mendukung pembuatan program aplikasi. Penulis telah berhasil membuat aplikasi Pemanfaatan E-Tourism Untuk Pemasaran Sektor Pariwisata Di Kota Makassar Berbasis Android. Proses perancangan Aplikasi menggunakan platform android menggunakan software android studio. Hasil evaluasi dari pengujian BlackBox untuk mengetahui keandalan aplikasi menunjukkan semua hasilnya valid atau sesuai harapan.
\end{abstract}

Kata Kunci: E-Tourism, Aplikasi E-Tourism, Destinasi Pariwisata.

\begin{abstract}
Abstrak
This research aims to design the utilization of E-tourism for the marketing of tourism sector in Makassar based on Android. The function of this research is to facilitate the vendors who want to find tourist sites and tourist attractions that want to buy or develop and other functions of the research is to facilitate the user to provide information to the vendors both institutions and individuals who want to develop or buy tourist attractions in the direction of data collection by studying materials, concepts, books and theories relating to the drafting process and the discussion of issues discussed by the authors included in the literature on authors and About things that support the creation of application programs. The author has managed to make application of E-Tourism utilization for tourism sector marketing in the city of Makassar based on Android. Application design process using Android platform using Android Studio software. Evaluation results from BlackBox testing to determine the reliability of the application shows that all results are valid or as expected.
\end{abstract}

Keywords: E-Tourism, application of E-Tourism, destination of tourism.

\section{PENDAHULUAN}

\subsection{Latar Belakang}

Pariwisata merupakan sektor yang ikut berperan penting dalam usaha peningkatan pendapatan. Indonesia merupakan negara yang memiliki keindahan alam dan keanekaragaman budaya, sehingga perlu adanya peningkatan pemasaran sektor pariwisata. Hal ini dikarenakan pariwisata merupakan sektor yang dianggap menguntungkan dan sangat berpotensi untuk dikembangkan sebagai salah satu aset yang di gunakan sebagai sumber yang menghasilkan bagi Bangsa dan Negara. Selain itu juga perlunya informasi jelas mengenai tempat-tempat wisata yang saat ini belum banyak diketahui oleh turis mancanegara maupun lokal. Oleh karena itu diperlukan dukungan atau sarana penyedia informasi baik majalah, iklan di tv dan media sosial dimana saat ini yang banyak mempromosikan tempat wisata di Indonesia. 
Objek wisata merupakan sesuatu tempat yang menjadi pusat daya Tarik dan dapat memberikan kepuasan khususnya wisatawan. Hal ini sangat penting untuk membudidayakan suatu destinasi wisata baik dengan mengembangkan dan menjaga kebudayaan itu sendiri. Pengembangan destinasi wisata ini menjadi acuan sebagai sumber penghasilan utama bagian setiap daerah. Hal ini dapat meningkatkan suatu tempat tujuan kunjungan terutama di Indonesia khususnya di kota Makassar. Oleh karena itu, pemerintahan daerah harus berupaya dalam mengembangkan berbagai destinasi wisata yang ada di kota Makassar.Pengembangan destinasi wisata dapat dilakukan dengan berbagai cara. Hal itu terlihat dari pemasaran objek wisata, acara tradisi adat daerah, pembudidayaan objek wisata, dan fasilitas yang mendukung. Pemasaran objek wisata merupakan salah satu daya Tarik objek wisata dalam menarik wisatawan. Tetapi banyak sekali pemasaran kurang dilakukan karena kurangnya pembiayaan dari pemerintah pusat salah satunya di Indonesia khususnya di kota Makassar banyak destinasi wisata yang ada di kota Makassar yang belum di pasarkan secara baik. Maka dari itu dibuatlah suatu aplikasi yang dimana memanfaatkan E-Tourism sebagai media pemasaran yang menghubung ke platform android yang dimana dalamnya terdapat fitur layanan pemasaran pariwisata yang ada di kota Makassar

Oleh karena itu, melihat permasalahan diatas perlu di buat sistem pemasaran yang memanfaatkan E-tourism untuk tempat wisata yang ada di Sulawesi selatan khususnya di kota Makassar menggunakan satu platform yang berbasis android dimana agar memudahkan para wisatawan baik dari mancanegara maupun lokal mencari tempat wisata yang murah dan terjangkau, dengan adanya platform tersebut wistawan dapat mengakses dengan satu palfrom yang disediakan nantinya dan tidak menutup kemungkinan tempat wisata lainnya yang ada di kota Makassar yang tidak kalah keren untuk dikunjungi oleh para wisatawan.

Rumusan masalah dalam penelitian ini adalah bagaimana E-tourism dalam pengenalan sektor pariwisata berbasis android di kota makassar.

Adapun tujuan penelitian ini adalah

1. Memudahkan para vendor yang ingin mencari lokasi wisata dan tempat wisata yang ingin di beli atau di kembangkan.

2. Memudahkan pengguna untuk memberi informasi kepada vendor baik instansi maupun perseorangan yang ingin megembangkan wisata yang di tuju.

Dalam penelitian sejenis dari Bagus Made Sabda Nirmala, Made Liandana yang berjudul “Aplikasi Trip Planner Berbasis Android Untuk Pariwisata Berbasis Desa Wisata Di Bali”. Penelitian ini membahas tentang mengembangkan aplikasi mobile berbasis Android Trip Planner, yang dapat digunakan oleh wisatawan untuk merencanakan perjalanan di Bali. Aplikasi ini memudahkan wisatawan dengan merencanakan sendiri perjalanannya dari satu tujuan wisata atau disebut Point of Interest (PoI) ke PoI yang lainnya. [1]

Sri Ipnuwati, Oktria Silviani, Wulandari Wulandari "Aplikasi E-Tourism Tempat Ibadah Dan Wisata Islamic Center Tulang bawang Barat" Penelitian ini membahas tentang E-tourism tempat ibadah dan wisata Islamic Center Tulang Bawang Barat ini dimaksudkan sebagai sarana mengakses informasi potensi Obyek Wisata Tulang Bawang Barat yang dapat memberikan rekomendasi tujuan wisata dan dapat dipublikasi kepada semua orang di seluruh dunia. Maraknya penggunaan internet di masyarakat menjadi sarana penyampaian informasi wisata yang di kembangkan dalam bentuk web, sehingga dengan media website informasi dapat diperoleh dengan cepat. Pemodelan sistem menggunakan Macromedia Dreamweaver untuk perancangan web, pengembangan sistem menggunakan PHP dan MySQL. [2]

Rizki Wahyudi, Ema Utami, M. Rudyanto Arief "Sistem Pakar E-Tourism Pada Dinas Pariwisata D.I.Y Menggunakan Metode Forward Chaining” Seiring dengan Visi dan Misi Dinas Pariwisata Kota Yogyakarta untuk meningkatkan daya saing dan penyerapan wisatawan dibutuhkan ide yang inovatif Salah satu alternatif yang dikembangkan dan dipandang efektif adalah dengan melakukan promosi melalui Internet. Saat ini telah berkembang promosi, pemasaran, dan penjualan produk pariwisata $(E-$ Commerce). Sedang dalam bidang Pariwisata yang berbasis teknologi informasi dikenal dengan sebutan E-Tourism. E-Tourism adalah pendigitalan semua proses dan merangkaikan keuntungan dalam lingkup pariwisata. Tujuan dari penelitian ini adalah untuk merancang sistem pakar yang mampu mengidentifikasi kriteria-kriteria obyek wisata untuk pemilihan destinasi. Sistem pakar ini berbasis web menggunakan pemrograman PHP dan MySQL sebagai basis data. Metode inferensi yang digunakan 
adalah forward chaining, yaitu memulai pencarian dari premis atau data masukan berupa kriteria-kriteria menuju pada konklusi yaitu obyek wisata dicari untuk penelusuran menggunakan Depth-first search. Pengujian dilakukan dengan dua cara yaitu pengujian Alpha menggunakan blackbox melakukan pengecekan permodule yang mana kesimpulannya semua module dapat bekerja dengan baik, kedua pengujian Beta menggunakan kuisioner dengan memakai variabel Usability dan Information Quality yang kesimpulannya 50\% responden aplikasi web dapat digunakan dengan mudah, $60 \%$ responden setuju aplikasi sesuai dengan kebutuhan untuk pemilihan obyek wisata. [3]

Herlina, Yulmaini, Sri Karnila, M. Ariza Eka Yusendra "Pengembangan Aplikasi E-Tourism Berbasis Android Sebagai Strategi Promosi Pariwisata Provinsi Lampung" Pembuatan Aplikasi ETourism mobile berbasis android untuk menyebarkan informasi dan mempromosikan potensi pariwisata di Provinsi Lampung dengan menggunakan metod penelitian kualitatif yang terutama untuk menentukan titik-titik pada tempat lokasi pariwisata di Provinsi Lampung dan penyusunan desain rancang bangun aplikasi ETourism menggunakan Software ARCGIS dengan metode metode prototype. Hasil yang dicapai pada penelitian tahun pertama ini adalah Arsitektur SIG berbasis mobile pada aplikasi E-tourism, Analisis Activity Diagram Pada Sistem, Rancangan Interface Admin. [4]

Apriani dan Pahrul Irfan Aplikasi E-Tourism sebagai Pendukung Promosi Pariwisata di Pulau Lombok. Penelitian ini bertujuan untuk membuat sebuah aplikasi e-tourism yang dapat diakses secara luas oleh masyarakat melalui halaman website. Aplikasi yang akan dikembangkan dapat digunakan untuk membantu wisatawan yang berkunjung ke Pulau Lombok untuk mengetahui objek wisata yang dilengkapi petunjuk arah menuju objek wisata. [5]

\section{TINJAUAN PUSTAKA}

\subsection{E-Turism}

Menurut Kementrian Pariwisata, E-Tourism adalah platform digital yang menghubungkan seluruh stakeholder pariwisata, mempermudah proses perizinan, mengintegrasikan seluruh kegiatan pariwisata serta memberikan kemudahan bagi seluruh wisatawan menjelajahi pesona Indonesia melalui aplikasi yang mudah digunakan, kapan pun dan di mana pun. E-tourism adalah sebuah perusahaan yang memanfaatkan teknologi informasi dan komunikasi dengan memberikan jasa layanan pariwisata kepada custumer secara on-line dan menjadikan penyelenggaraan pemasaran pariwisata lebih mudah di akses.

Hal ini memungkinkan penyebaran informasi mengenai pengembangan pariwisata bisa diakses kapan saja.

\subsection{Pariwisata}

Istilah pariwisata berasal dari bahasa Sansekerta yang terdiri dari suku kata "pari" berarti berkeliling atau bersama, dan suku kata "wisata" berarti perjalanan. Jadi secara pengertiannya pariwisata berarti perjalanan keliling dari suatu tempat ke tempat lain. Menurut Kamus Besar Bahasa Indonesia pengertian wisata adalah bepergian secara bersama-sama dengan tujuan untuk bersenang-senang, menambah pengetahuan, dan lain-lain. Selain itu dapat diartikan dengan bertamasya atau piknik. Pariwisata atau turisme adalah suatu perjalanan yang dilakukan untuk rekreasi atau liburan dan juga persiapan yang dilakukan untuk aktivitas ini, (wikipedia)

Menurut James J. Spillane pariwisata adalah kegiatan melakukan perjalanan dengan tujuan mendapatkan kenikmatan, mencari kepuasan, mengetahui sesuatu, memperbaiki kesehatan, menikmati olahraga, menunaikan tugas, berziarah Dan lain sebagainya.

\subsection{Android}

Android adalah sistem operasi berbasis Linux yang dirancang untuk perangkat bergerak layar sentuh seperti telepon pintar dan komputer tablet. Android awalnya dikembangkan oleh Android, Inc., dengan dukungan finansial dari Google, yang kemudian membelinya pada tahun 2005. Sistem operasi ini dirilis secara resmi pada tahun 2007, bersamaan dengan didirikannya Open Handset Alliance, konsorsium dari perusahaanperusahaan perangkat keras, perangkat lunak, dan telekomunikasi yang bertujuan untuk memajukan standar terbuka perangkat seluler. Ponsel Android pertama mulai dijual pada bulan Oktober 2008. Antarmuka pengguna Android umumnya berupa manipulasi langsung, menggunakan gerakan sentuh yang serupa dengan tindakan nyata, misalnya menggeser, 
mengetuk, dan mencubit untuk memanipulasi objek di layar, serta papan ketik virtual untuk menulis teks. Selain perangkat layar sentuh, Google juga telah mengembangkan Android TV untuk televisi, Android Auto untuk mobil, dan Android Wear untuk jam tangan, masingmasingnya memiliki antarmuka pengguna yang berbeda. Varian Android juga digunakan pada komputer jinjing, konsol permainan, kamera digital, dan peralatan elektronik lainnya.

\section{METODE PENELITIAN}

\subsection{Alur Penelitian}

Metode Pengumpulan data ini dimulai dari tahap perumusan masalah, lalu tujuan penelitian, dilanjutkan dengan pengumpulan data, dimana data yang dibutuhkan adalah data pendukung yang relevan. Metode pengumpulan data yang digunakan untuk penelitian adalah studi pustaka. Kemudian peneliti menetapkan topik penelitian dan metode yang akan diterapkan serta aplikasi yang akan dibuat.

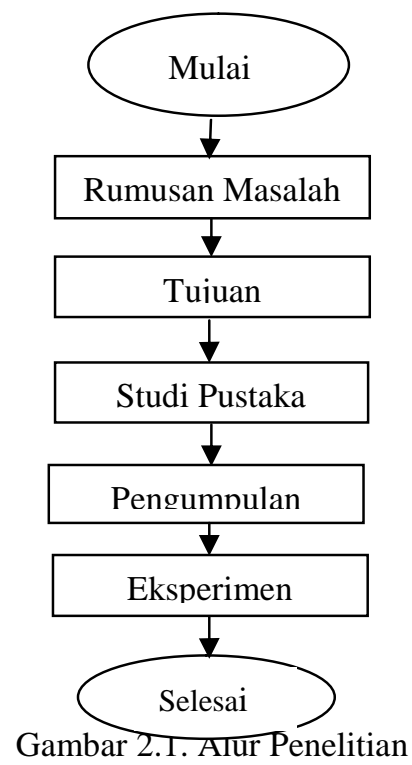

\subsection{Jenis Penelitian}

Pada tahap ini peneliti memulai dari rumusan masalah yang akan diteliti berdasarkan kondisi tempat wisata yang ada di kota Makassar yaitu mengidentifikasi masalah dimana saat ini banyak wisatawan yang belum mengetahui tempat destinasi wisata yang ada di kota Makassar, hal itu mengakibatkan kurangnya kunjungan wisatawan yang berkunjung ketempat wisata yang ada di kota Makassar, lalu tujuan penelitian dan selanjutnya penulis melakukan studi pustaka dengan mengumpulkan data dan mempelajari bahan, konsep, buku-buku dan teori yang berkaitan dengan proses penyusunan dan pembahasan masalah yang di bahas oleh penulis dan mengenai hal-hal yang mendukung pembuatan program aplikasi. Selain itu penulis juga melakukan pengumpulan data dengan tanya jawab secara langsung kepada masyarakat di kota Makassar. Pada tahap ini, peneliti telah menentukan pemanfaatan E-Tourism sebagai cara agar dapat merancang aplikasi pemasaran sektor pariwisata di kota makassar sehingga peneliti membuat beberapa pertanyaan dan melakukan wawancara dengan tujuan untuk mendapatkan fitur dan alur proses aplikasi tersebut.

\subsection{Pengujian}

Pada tahap ini penulis melakukan pengujian perangkat lunak dari segi spesifikasi fungsional tanpa menguji desain dan kode program. Pengujian dimaksudkan untuk mengetahui apakah fungsi-fungsi, masukan, dan keluaran dari perangkat lunak sesuai dengan spesifikasi 
yang dibutuhkan. Pengujain yang dilakukan penulis diantaranya ialah: a) Pengujian Aplikasi, b) Pengujian Tools Aplikasi, dan c) Evaluasi Paplikasi

\subsection{Alat Penelitian}

Adapun alat dan bahan penelitan yang digunakan penulis antara lain :

a. Alat dan bahan studi kepustakaan; 1) Pulpen, Buku Catatan, 2) Kertas HVS dan 3) Paperpaper Para Peneliti

b. Alat dan bahan Perancangan serta Pengetesan Aplikasi, alat dan bahan yang

di gunakan adalah: 1) Software: Android Studio, Windows Operating System 2010, XAMPP, Corel Draw, Microsoft Office 2013 dan 2) Hardware: Asus VivoBook Core $i 7$.

\section{HASIL DAN PEMBAHASAN}

Berikut akan dijabarkan analisis penelitian berdasarkan rancangan ini untuk user sebagai pengguna sistem yaitu E-Tourism. Pada aplikasi tersebut terdapat fitur destinasi wisata yang ada di kota Makassar dan user dapat mengakses fitur dimaksud untuk mendapatkan informasi mengenai sektor pariwisata yang berada di kota Makassar melalui platform android yang dibuat khusus untuk destinasi wisata yang ada di kota Makassar.

Aplikasi ini juga memiliki fitur-fitur dan user dapat mengakses aplikasi dengan login terlebih dahulu. User juga dapat melihat tempat destinasi wisata yang ada di kota Makassar, selain itu user juga dapat menambahkan tempat wisata yang belum diketahui oleh orang-orang atau tourist asing. Kemudian setelah user menambahkan tempat destinasi wisata maka otomatis data tersebut akan ditambahkan kedalam database dan fungsi admin adalah untuk mengkonfirmasi data yang telah di unggah oleh pengguna, apakah data pariwisata tersebut valid atau tidak.

\subsection{Rancangan Umum}

Pada arsitektur aplikasi ini penulis menjelaskan bahwa user dapat mengakses aplikasi dengan login terlebih dahulu. Selanjutnya untuk tempat destinasi wisata yang telah ditambahkan oleh pengguna secara otomatis akan ditambahkan kedalam database, kemudian vendor dapat melihat lokasi wisata dan admin juga dapat mengkonfirmasi data yang telah di unggah oleh pengguna, sehingga dapat dilihat apakah data pariwisata tersebut valid atau tidak.

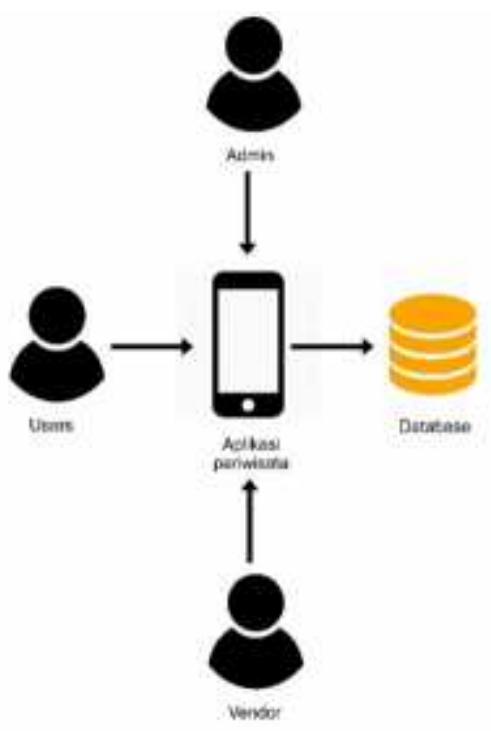

Gambar 1 : Arsitektur aplikasi 


\subsection{Tahap Inteligensi}

Pada tahap ini penulis menjelaskan bahwa user dapat mengakses menu utama aplikasi, user juga dapat login dan melihat data wisata, melihat detail wisata juga melihat merekomendasi wisata bahkan menambahkan komentar dan membalas komentar. User juga dapat menambah data wisata. Selain itu user dapat logout dari aplikasi tersebut. Juga terdapat vendor yang dapat mengakses menu utama, login, lihat data wisata dan menambahkan komentar.

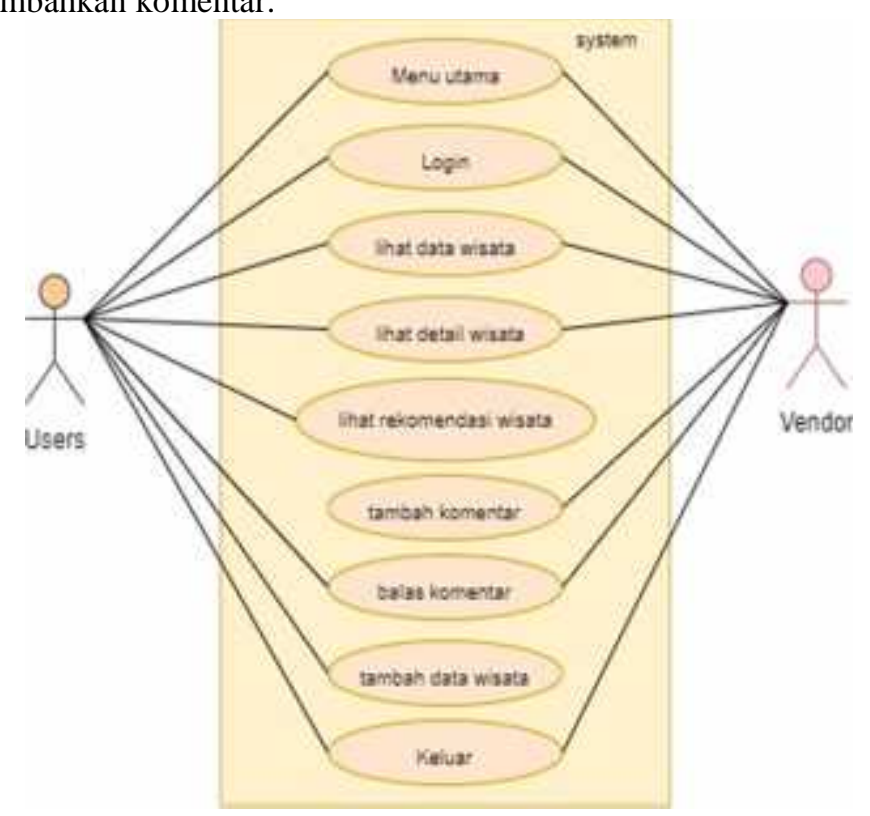

Gambar 2 : Use Case Diagram

\section{a. Tahap Perancangan}

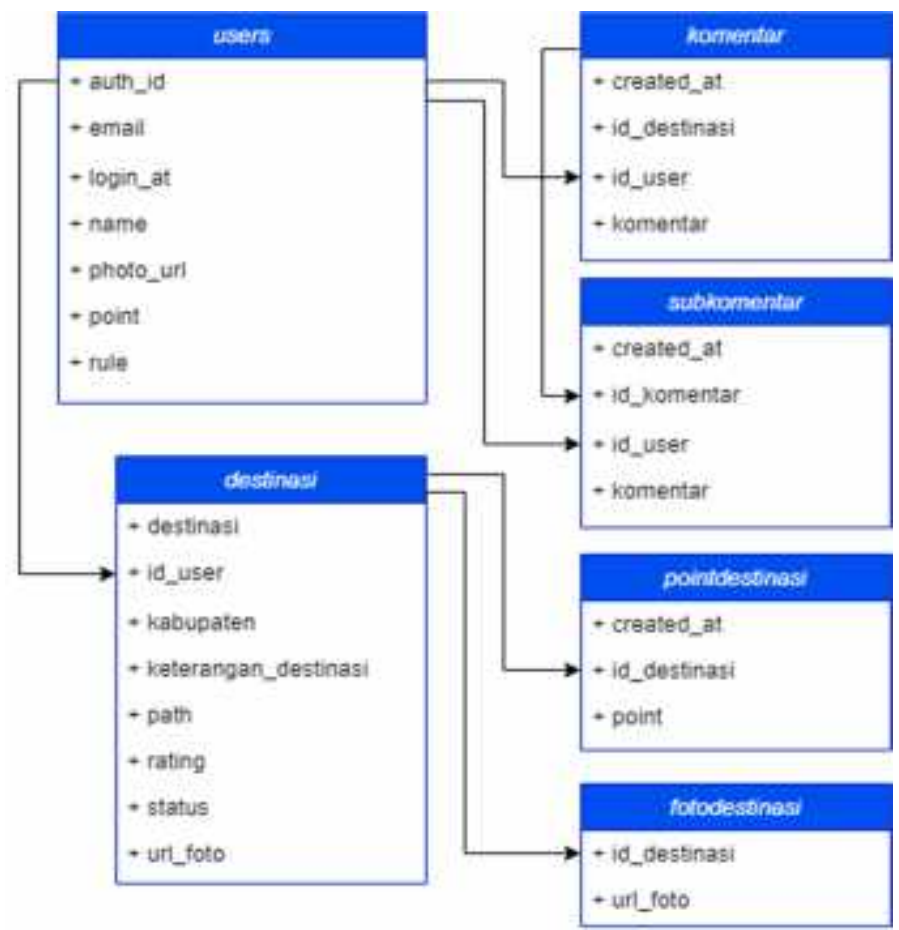

Gambar 3 : Class Diagram

i. $\quad$ Rancangan input

a. Nama : Halaman Tambah destinasi

Fungsi : Untuk menambahkan tempat destinasi wisata 
Tabel : destinasi

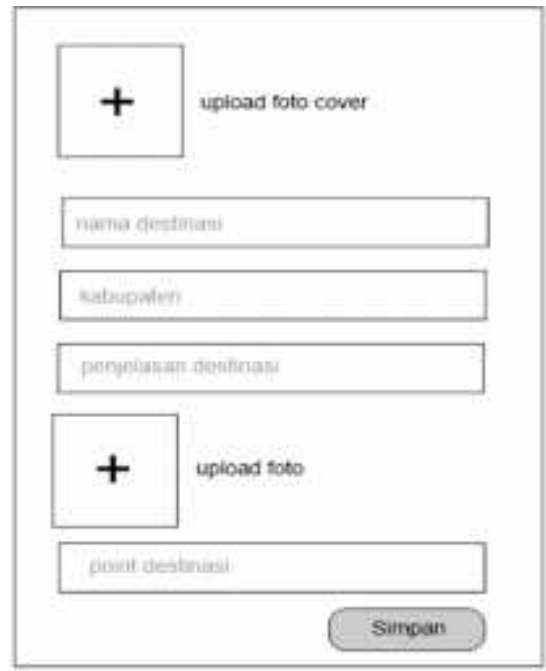

Gambar 4 : Halaman Tambah destinasi

b. Nama : Halaman Tambah komentar

Fungsi : Untuk menambahkan komentar

Tabel : komentar

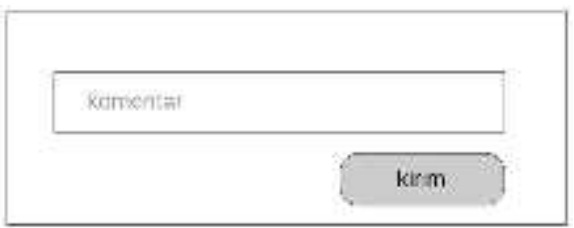

Gambar 5 : Tambah komentar

\subsubsection{Rancangan output}

a. Nama : Halaman data pariwisata

Fungsi : Untuk melihat daftar data pariwisata

Tabel : Data Pariwisata

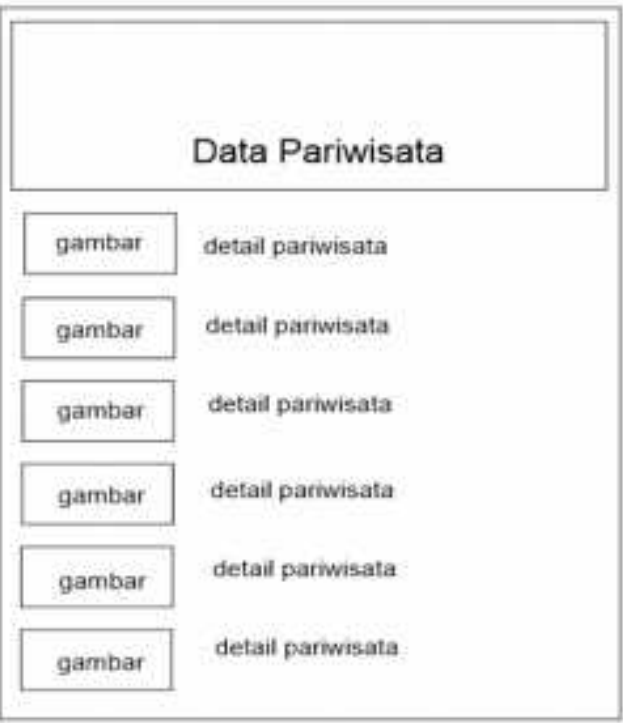

Gambar 6 : Halaman data pariwisata 
b. Nama : Halaman rincian data pariwisata

Fungsi : Untuk melihat daftar rincian data pariwisata

Tabel : destinasi

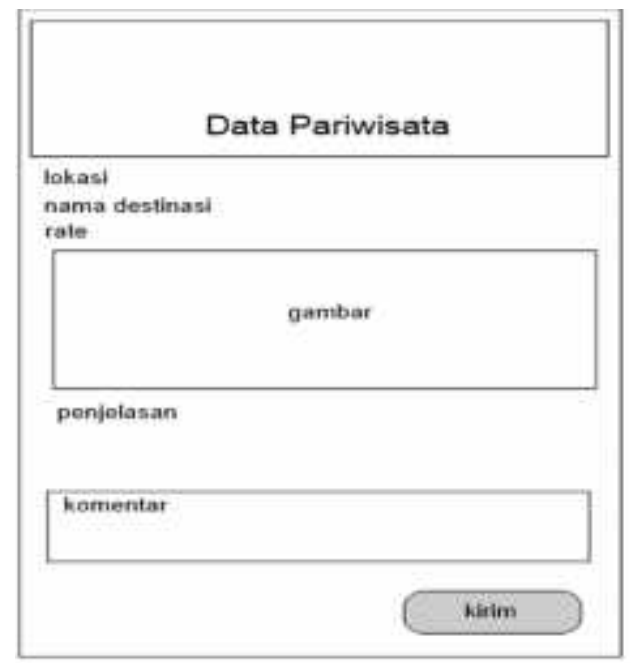

Gambar 7 : Halaman rincian data pariwisata

\subsection{Implementasi}

Berikut beberapa contoh tampilan antarmuka e-tourism dalam pengenalan sektor pariwisata berbasis android di kota Makassar serta spesifikasi perangkat hardware dan software yang digunakan: $a$ ) Sistem operasi windows 10,b) Laptop ASUS Core i7, c) RAM dengan kapasitas 8 GB, d) Hardisk dengan kapasitas $1 \mathrm{~TB}$, e) Firebase, f) Android studio,

g) Smartphone Oppo A9 2020

\subsubsection{Implementasi Tampilan Antarmuka}

a. Tampilan Menu Utama Pengguna

Tampilan Halaman Utama menampilkan Selamat datang, daftar data wisata dan rekomendasi tempat wisata. Selain itu terdapat tombol masuk yang berfungsi agar user dapat login ke aplikasi.
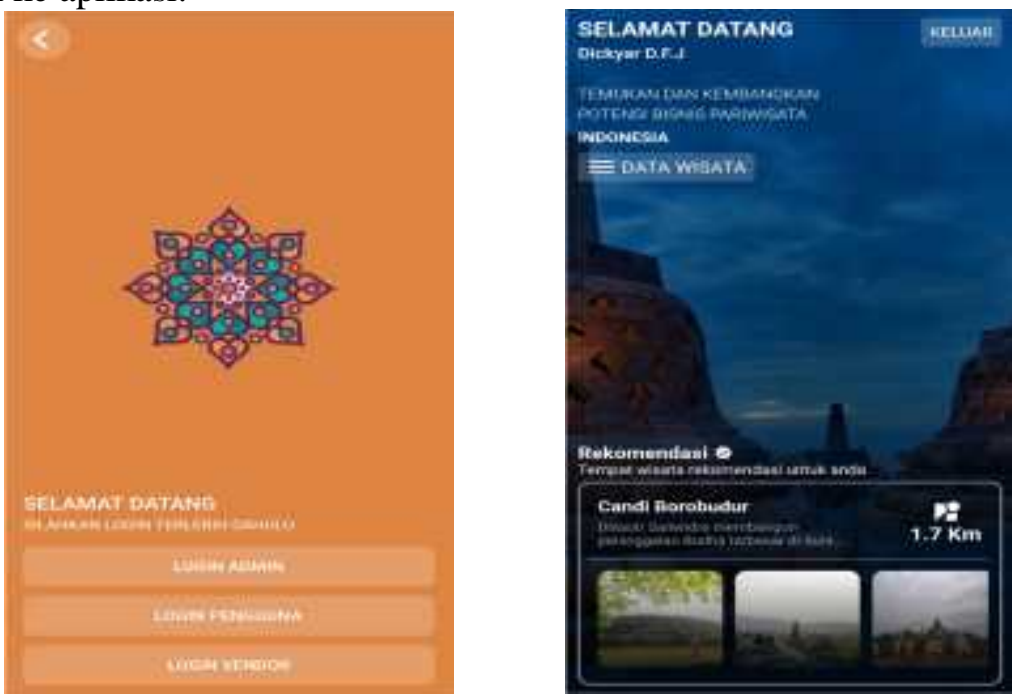

Gambar 8 : Menu Utama Pengguna 
b. Tampilan Login

Tampilan halaman login berfungsi agar user dapat mengakses kedalam aplikasi. Halaman login menampilkan input akun Google. Adapun tampilan halaman login dapat dilihat pada Gambar 9.

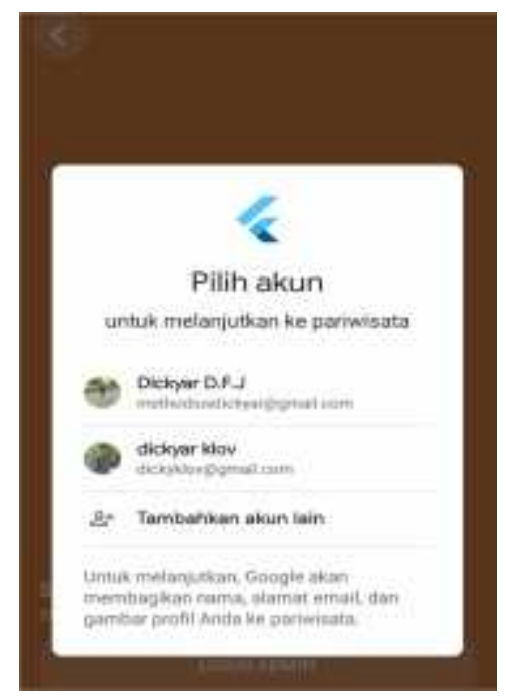

Gambar 9 : Login

c. Tampilan Data Pariwisata Pengguna

Tampilan halaman daftar data pariwisata pada aplikasi android menampilkan daftar data pariwisata yang ada di kota Makassar. Tampilan halaman daftar data pariwisata dapat dilihat pada Gambar 10.
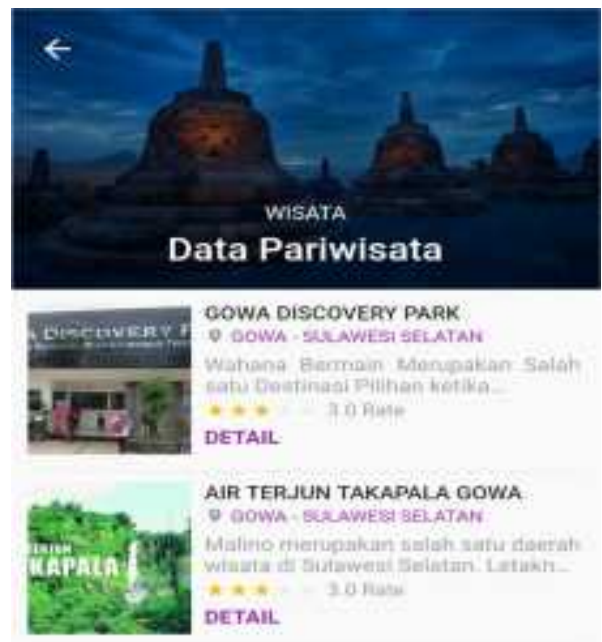

Gambar 10 : Data Pariwisata Pengguna

d. Tampilan Detail Pariwisata Pengguna

Tampilan halaman detail data pariwisata pada aplikasi android menampilkan detail pariwisata. Tampilan halaman dapat dilihat pada Gambar 5.4. 


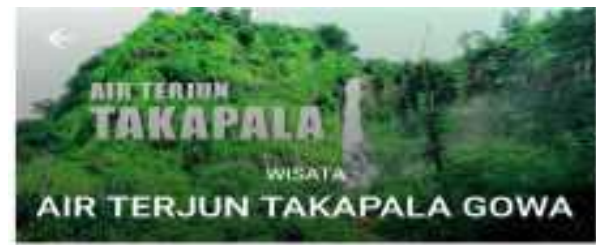

- gowa-gulawesi selataA

AIR TERJUN TAKAPALA GOWA

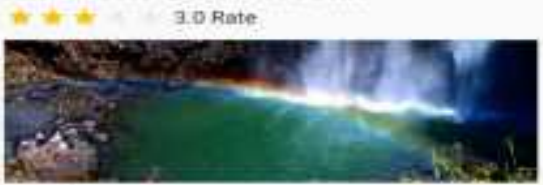

Dipublikani Oleh

Dichyar Dasy

Pentetasan:

Malino merupakan salah satic doesiah wasata of

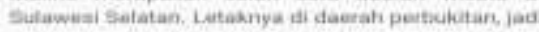

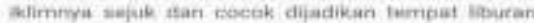

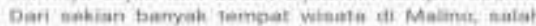

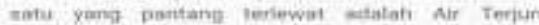
Takapata Air Tartun Tokopota berada di mebeniab barat Gurrung Bawokmaeng dan-Gunung Lompobattants Jikn berventung penguriveng botken bisn melitist

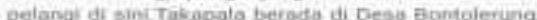

Gambar 11 : Detail Pariwisata Pengguna

e. Tampilan Halaman Komentar Pengguna

Tampilan halaman komentar pada aplikasi android menampilkan daftar komentar user lain dan komentar sendiri. Tampilan halaman komentar dapat dilihat pada Gambar 12.

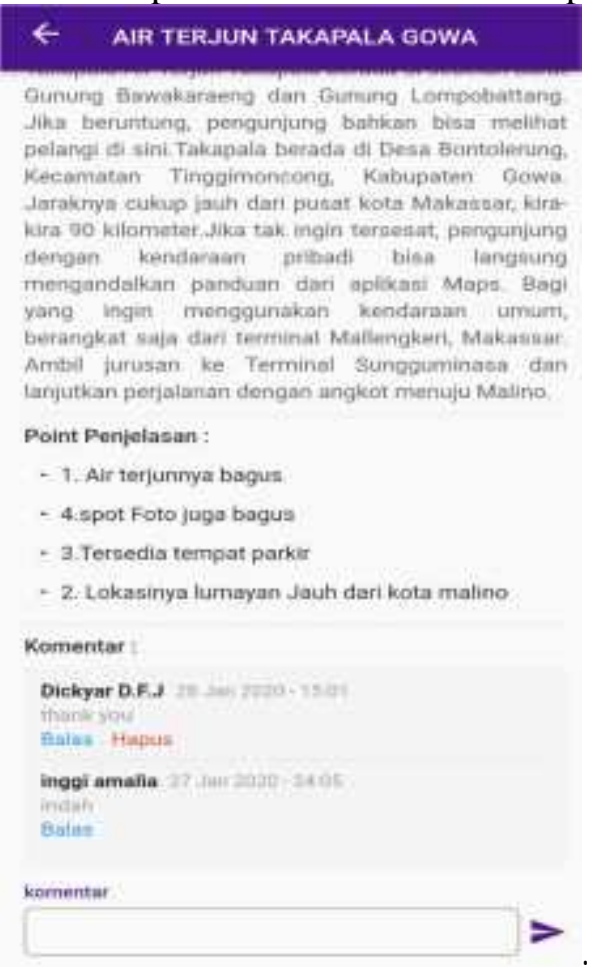

Gambar 12 : Komentar Pengguna

f. Tampilan Halaman Tambah Destinasi Pariwisata Pengguna

Tampilan halaman ini menampilkan daftar inputan daftar destinasi pariwisata yang akan di tambahkan oleh pengguna. Tampilan halaman ini dapat dilihat pada Gambar 12 


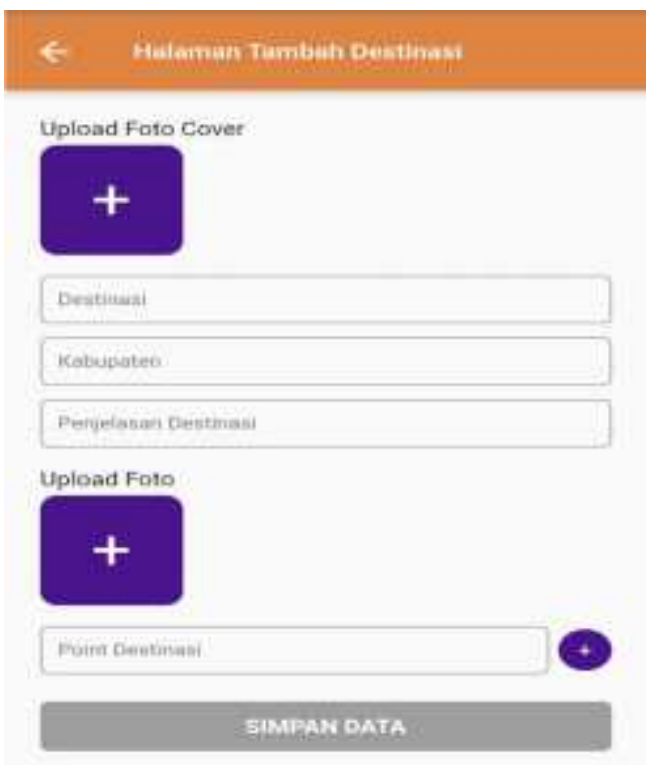

Gambar 12 : Tambah Destinasi Pariwisata

g. Tampilan Menu Utama Admin

Tampilan Halaman Utama menampilkan Selamat datang, daftar data wisata, Konfirmasi data wisata dan rekomendasi tempat wisata. Selain itu terdapat tombol masuk yang berfungsi agar user dapat login ke aplikasi. Tampilan halaman ini dapat dilihat pada Gambar 13.

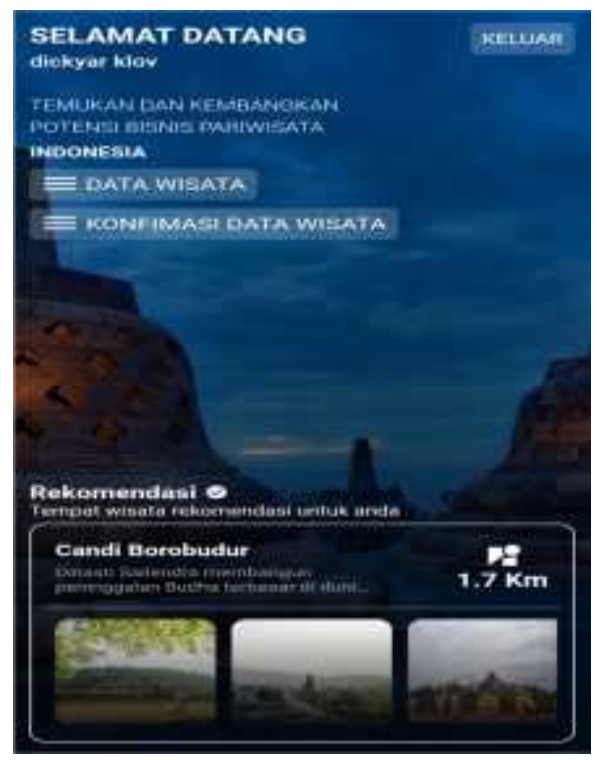

Gambar 13 : Menu Utama Admin

h. Tampilan Konfirmasi Data Admin

Tampilan halaman konfirmasi data pada aplikasi android menampilkan daftar lokasi tempat pariwisata yang direkomendasi user lain. Tampilan halaman ini dapat dilihat pada Gambar 13. 


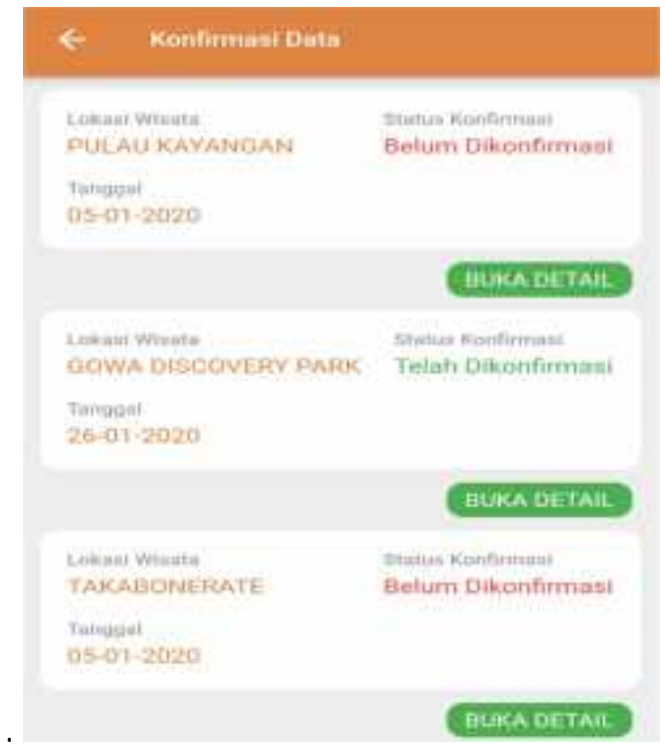

Gambar 13 : Konfirmasi Data Admin

i. Tampilan Halaman Data Pariwisata Admin

Tampilan halaman daftar data pariwisata pada aplikasi android menampilkan daftar data pariwisata yang ada di kota Makassar. Tampilan halaman daftar data pariwisata dapat dilihat pada Gambar 14
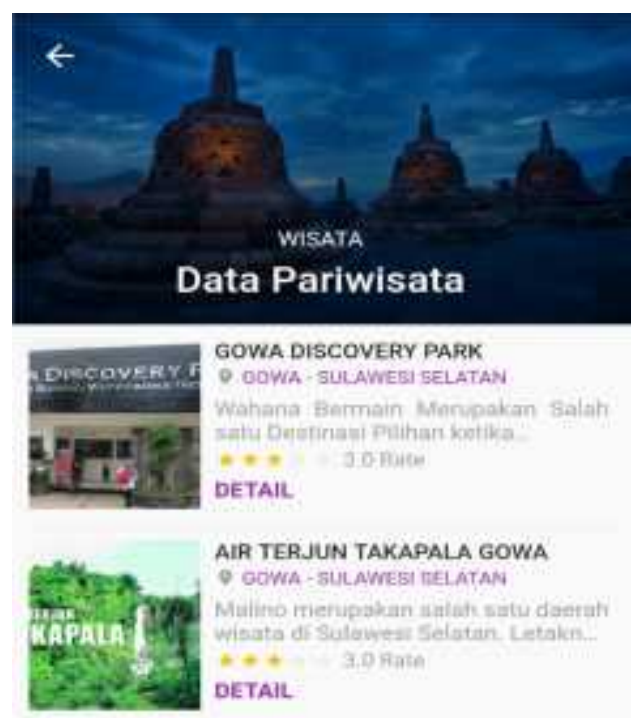

Gambar 14 : Data Pariwisata Admin

j. Tampilan Komentar Admin

Tampilan komentar pada aplikasi android menampilkan daftar komentar user lain dan komentar sendiri. Tampilan halaman komentar dapat dilihat pada Gambar 15. 


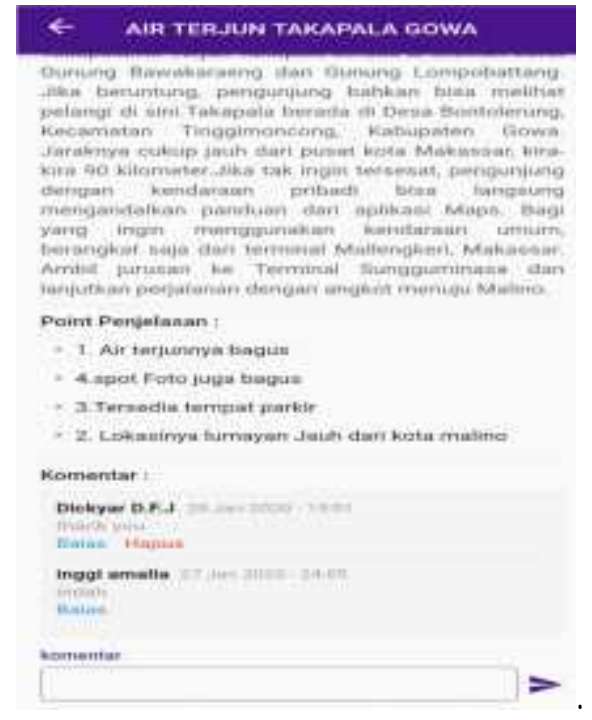

Gambar 15 : Halaman Komentar Admin

\section{Kesimpulan}

Berdasarkan hasil pembahasan dan informasi yang diperoleh, maka penulis dapat menarik beberapa kesimpulan:

1. Penulis telah berhasil membangun sistem e-tourism dalam pengenalan sektor pariwisata berbasis android di kota Makassar

2. Proses ini menggunakan platform android menggunakan software android studio. Hasil dan hasil dari sistem ini dapat memberi informasi kepada user maupun vendor tentang e-tourism dalam pengenalan sektor pariwisata berbasis android di kota Makassar

\section{DAFTAR PUSTAKA}

[1] Brady dan Loonam (2010), Entity Relationship diagram (ERD)

[2] Gemino, A., Parker, D. (2009) "Use case diagrams in support of use case modeling:Deriving understanding from the picture", Journal of Database Management, 20(1), 1-24.

[3] Sri Ipnuwati, Oktria Silviani, Wulandari Wulandari 2018 "Aplikasi E-Tourism Tempat Ibadah Dan Wisata Islamic Center Tulang bawang Barat".

[4] Bagus Made Sabda Nirmala, Made Liandana 2018 “Aplikasi Trip Planner Berbasis Android Untuk Pariwisata Berbasis Desa Wisata Di Bali”.

[5] Herlina, Yulmaini, Sri Karnila, M. Ariza Eka Yusendra 2015. "Pengembangan Aplikasi E Tourism Berbasis Android Sebagai Strategi Promosi Pariwisata Provinsi Lampung”

[6] Rizki Wahyudi, Ema Utami, M. Rudyanto Arief 2016. "Sistem Pakar E-Tourism PadaDinas Pariwisata D.I.Y Menggunakan Metode Forward Chaining”

[7] Wahyu Istuningsi, Universitas Sebelas Maret. 2018. Dongkrak Industri Pariwisata melalui "E-Tourism: strategi promosi zaman now. Kompasiana.com, di akses tanggal 18 Mei 2019. Link:

https://www.kompasiana.com/wahyuistuningsih/5a4f6086bde57534b61605e2/dongkrak-industripariwisata-melalui-e-tourism-strategi-promosi-zaman-now\#

[8] William J. Stanton, Prinsip Pemasaran, Alih Bahasa Wilhelmus W. Bokowatun, Erlangga, Jakarta, 1991, hlm. 5. 